\title{
Some Properties of a Cytopathogenic Bovine Orphan Virus (Van den Ende Strain)
}

\author{
A. KIPPS, G. S. TURNER AND A. POLSON \\ Council for Scientific and Industrial Research and University of Cape Town's \\ Virus Research Unit, University of Cape Town, South Africa
}

(Received 14 March 1961)

\section{SUMMARY}

A cytopathogenic bovine orphan (CBO) virus isolated from a bovine with lumpy skin disease appears unrelated to any of the three groups of viruses now associated with this condition. The virus multiplies efficiently in cultures of whole chick embryo tissue and may be titrated by plaque counting methods. Tissue culture fluids contain infective particles of at least three sizes, with sedimentation constants of 460 , 72 and $20 \mathrm{~S}$. The intermediate particle, if spherical and lipid free, would be comparable in size to the virus of foot and mouth disease. Heterogeneity of the virus has also been demonstrated by plaque morphology, electrophoresis and chromatography on DEAE cellulose. It is adsorbed to fresh but not to receptor-destroying enzyme (RDE) treated red cells of chicken and goose, but haemagglutination has not been observed with cells of any of the species tested. The virus lacks enzyme activity comparable to that of influenza virus.

\section{INTRODUCTION}

While investigating the etiology of bovine lumpy skin disease, Van den Ende, Alexander, Don \& Kipps (1948) and Van den Ende, Don \& Kipps (1949) reported the isolation in eggs of a virus from a skin nodule and a lymph gland of a calf which had died while the disease was still active. This virus produced unique and characteristic lesions in chick embryos. By common usage and in affection for the late Director of the Virus Research Unit, this virus has come to be known throughout the Union of South Africa as the 'Van den Ende Virus' but it is better called the Van den Ende strain of a cytopathogenic bovine orphan (CBO) virus. What appeared to be a successful transmission of the disease to bovines by inoculation of material from the 66th egg passage (Van den Ende \& Turner, 1950), led to the assumption that this virus was in fact the cause of lumpy skin disease (Polson \& Turner, 1954). Further studies, however, did not confirm this association and the earlier apparently successful transmission was recognized in retrospect as a natural infection in the laboratory herd.

The etiology of lumpy skin disease is now well known, and Alexander, Plowright \& Haig (1957) reported the isolation of three groups of viruses from bovines suffering from the disease; of these viruses the prototypes Allerton virus and Neethling virus are representative of the responsible etiological agents. Although numerous isolations of these two viruses have been made, neither of them bears any relationship to the virus described in this paper. Attempts to re-isolate CBO virus from 
bovines with lumpy skin disease have all been unsuccessful. An enteric cytopathogenic bovine orphan (ECBO) virus isolated during this investigation was found to possess some of the characters of the Van den Ende strain but was antigenically distinct. The present paper describes some of the physical and biological properties of the Van den Ende strain of CBO virus. The effect of inhibitors present in normal animal sera upon this virus is discussed in another communication (Turner, Kipps, Polson \& Van den Ende, 1961).

\section{Virus}

\section{METHODS}

After its isolation, CBO virus was at first maintained by periodic amniotic or allantoic passage in chick embryos. Later it was found to be stable after drying from the frozen state, and active lyophilized reference stocks of the 16th egg passage have been kept for many years.

\section{Propagation in tissue culture}

CBO virus grows readily in cultures of whole chick embryo tissue. Cell suspensions were prepared by tryptic digestion of 9-10 day chick embryos and grown in a medium consisting of $\mathbf{0 . 5} \%(\mathrm{w} / \mathrm{v})$ lactalbumin hydrolysate in Hanks balanced salt solution with $20 \%(\mathrm{v} / \mathrm{v})$ horse serum. In the maintenance medium the serum was omitted.

Virus stocks for the majority of the experiments were harvested from Roux flask cultures when cytopathic changes were complete, approximately 3 days after inoculation. After light centrifugation to remove tissue debris, the supernatant fluid was stored in sealed glass ampoules at $-70^{\circ}$. There was little loss of infectivity over a period of many months.

\section{Titration}

The titration of the virus in eggs has been described (Van den Ende \& Turner, 1950). Titrations in tissue culture were carried out by the plaque techniques of Dulbecco (1952) and Cooper (1955). Chick embryo cultures were prepared in $4 \mathrm{~cm}$. diameter Petri dishes using not less than $1 \times 10^{7}$ cells $/$ dish in 3 ml. nutrient medium and duplicate dishes were seeded with $0.2 \mathrm{ml}$. volumes of virus suspension or serumvirus mixture. The plates were incubated at $37^{\circ}$ in air containing about $5 \%(\mathrm{v} / \mathrm{v})$ $\mathrm{CO}_{2}$ for 2 days, after which they were flooded with $1 / 5000$ neutral red in Earle's saline. The dye was removed after $2 \mathrm{hr}$. when the plaques could be easily counted. Repeat counts were made next day. Titres were expressed as plaque forming units (p.f.u.).

\section{Antisera}

Immune sera were produced in fowls and rabbits. Adult hens were inoculated with graded intramuscular doses of emulsions of infected embryos. The intravenous route was used for the rabbits. Blood was collected 10-12 days after the last of a course of 7-8 injections given twice weekly. The blood was allowed to clot and the separated serum heated at $56^{\circ}$ for $30 \mathrm{~min}$. and stored at $-20^{\circ}$. 


\section{Neutralization tests}

Two methods were used. In the first, a single concentration of virus known to produce about 60 plaques/plate was used. Unit volumes of tenfold dilutions of serum were mixed with equal volumes of the virus dilution, the mixtures allowed to stand at room temperature for $1 \mathrm{hr}$. and each mixture then used to inoculate duplicate agar suspension cultures of chick embryo cells (Cooper, 1955).

In the second method serial tenfold dilutions of both serum and virus were used so that the titre of the virus in the presence of different concentrations of antibody or inhibitor could be measured. The time of contact and the method of plating were the same as in the method employing a single concentration of virus.

\section{Zone electrophoresis}

The technique of Polson \& Cramer (1958) was used. The virus suspension was mixed with phenol red and rabbit haemoglobin as reference substances. Electrophoresis was allowed to proceed at room temperature under a voltage gradient of $3.5 \mathrm{~V} . / \mathrm{cm}$. and a current of $15 \mathrm{~mA}$. through a sucrose density gradient ( 35 to $0 \%$ ) in borate buffer ( $\mathrm{pH} \mathrm{8 \cdot 6)}$ until the phenol red reached a level of $16 \mathrm{~cm}$. from the origin. The gradient column between the origin and the phenol red was divided into 16 equal fractions by removal through a fine capillary at the bottom of the column. Each fraction was titrated for infectivity in agar suspension cultures of chick embryo cells (Cooper, 1955).

\section{Ultracentrifugation}

Sedimentation coefficients were determined by the methods of Polson \& Van Regenmortel (to be published) using the S.W. 39 rotor of the model LH Spinco centrifuge at temperatures below $4^{\circ}$. In these methods convection was prevented by a steep sucrose concentration gradient below the layer of virus suspension. In a series of tubes the length of the 'effective virus column' was kept constant at $1 \mathrm{~cm}$. After centrifugation the whole of the fluid above the sucrose gradient was removed and titrated. In this way the conditions of centrifugation necessary to cause sedimentation of the virus through a measured distance were accurately maintained. Series of tubes prepared as indicated were centrifuged either at constant rotor velocity for different time intervals, or for constant periods of time at various rotor velocities.

The sedimentation constants of the particles under investigation were calculated from the following equations:

$$
S_{20}=3 \cdot 50 \frac{\eta_{T}}{\eta_{20}} \frac{\log X}{N^{2} t}
$$

where $\eta_{T}$ and $\eta_{20}$ are the viscosities of the dispersion medium at the temperature of centrifugation and of water at $20^{\circ}$ respectively, $N$ the rotor velocity in rev./min. and $t$ the time of centrifugation in minutes,

$$
X=\frac{x+l}{x+l\left(C_{t} / C_{0}\right)}
$$

in which $x$ is the distance from the upper meniscus to the centre of rotation, $l$ is the effective column (i.e. the distance between the upper meniscus and the upper limit 
of the sucrose gradient), and $C_{t} / C_{0}$ the ratio of average virus or protein concentration in the 'effective column' after and before ultra-centrifugation.

\section{$D E A E$ chromatography}

The $\mathrm{CBO}$ virus in infected tissue culture fluid was concentrated by pervaporation and centrifugation at $30,000 \mathrm{rev} . / \mathrm{min}$. for $2 \mathrm{hr}$. The final pellet was suspended in $2 \mathrm{ml}$. distilled water and applied to a $10 \mathrm{~cm}$. column of DEAE cellulose (Peterson \& Sober, 1956), containing 0.7 g. of adsorbent which had been equilibrated with $0 \cdot 01$

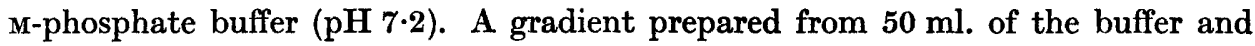
$50 \mathrm{ml}$. of $\mathrm{M}-\mathrm{NaCl}$ was used for elution. Twenty-five $2 \mathrm{ml}$. fractions were collected and titrated individually in chick embryo tissue culture by the plaque technique.

\section{Enzymes}

Dried commercial receptor-destroying enzyme (RDE; Philips-Roxane) was reconstituted to the volume recommended by the manufacturer in $\mathrm{pH} 6.0$ buffer containing 100 units penicillin and $100 \mu \mathrm{g}$. streptomycin/ml. Active influenza $\mathbf{B}$ virus (Lee) propagated in eggs according to well known standard techniques was used as a source of neuraminidase.

\section{RESULTS}

\section{Adaptation of virus to tissue culture}

Virus passaged in chick embryos grew well in chick embryo tissue cultures and produced plaques. The ratio of p.f.u./ml. to the titre in chick embryo was relatively low in extracts of infected embryos and in fluid obtained from the first two or three passages in tissue culture, but the ratio increased rapidly to a value which remained almost constant after many passages in tissue culture (Table 1). The typical lesions are still regularly observed in chick embryos inoculated with the tissue culture adapted virus.

Table 1. The adaptation of CBO virus to chick embryo tissue culture and the ratio of $p . f . u . / m l$. to the titre in eggs

\begin{tabular}{lcc}
\multicolumn{1}{c}{ Virus } & p.f.u./ml. & $\begin{array}{c}\text { Titre in eggs } \\
\text { (LD 50/ml.) }\end{array}$ \\
$\begin{array}{l}\text { Suspension of virus-infected egg } \\
\text { Suspension from plate tissue culture after 1 TC }\end{array}$ & $10^{3 \cdot 8}$ & $10^{6 \cdot 2}$ \\
$\begin{array}{l}\text { passage } \\
\text { Suspension from plate TC after 3 TC passages }\end{array}$ & $10^{4 \cdot 4}$ & $10^{7 \cdot 2}$ \\
Suspension from plate TC after 4 TC passages & $10^{6 \cdot 1}$ & $10^{7 \cdot 3}$ \\
& $10^{6 \cdot 2}$ & $10^{7 \cdot 2}$
\end{tabular}

\section{Plaque morphology}

After incubation at $37^{\circ}$ for about $48 \mathrm{hr}$. two types of plaque were encountered. One was well defined and 1-2 mm. in diameter while the other, appearing in roughly equal numbers, was less well defined and measured 2-5 $\mathrm{mm}$. in diameter. Incubation for another $24 \mathrm{hr}$. resulted in the enlargement of existing plaques and the appearance of many secondary plaques. On subculture, virus from either type of plaque yielded a mixture of the two. 


\section{Neutralization tests}

The concentration of the virus clearly has an important bearing on the apparent neutralizing titre of the serum (Table 2). Most CBO fowl immune sera in dilutions of $10^{-3}$ showed significant neutralization. These sera did not neutralize the Allerton and Neethling strains of lumpy skin disease virus.

Titration of antibodies to CBO virus in bovine sera of both normal animals and those convalescent from lumpy skin disease were found to be unreliable owing to the non-specific neutralization by inhibitors in both groups of sera. Neutralization tests with CBO antisera produced in rabbits were similarly complicated by the presence of high titre non-specific inhibitors. These inhibitors were found in many other animal sera in varying concentration (Turner et al. 1961).

Table 2. Neutralization of the virus by ford immune serum in agar suspension cultures of chick embryo cells

c, confluent plaques; sc, semi-confluent plaques.

$\begin{array}{ccccccc}\begin{array}{c}\text { Virus } \\ \text { dilution }\end{array} & \overbrace{10^{-1}} & \begin{array}{c}\text { Average number of plaques/plate } \\ \text { serum dilution }\end{array} & 10^{-3} & 10^{-4} & 10^{-5} & \begin{array}{c}\text { without } \\ \text { control } \\ \text { serum }\end{array} \\ 10^{-2} & 0 & 12 & \text { c } & - & - & \text { c } \\ 10^{-3} & 0 & 1 & 58 & \text { c } & - & \text { c } \\ 10^{-4} & 0 & 0 & 35 & \text { sc } & \text { se } & \text { c } \\ 10^{-5} & 0 & 0 & 0 & 22 & 37 & 37 \\ 10^{-6} & 0 & 0 & 1 & 3 & 6 & 5\end{array}$

\section{Animal inoculation}

Numerous attempts were made to develop a pathogenicity test in animals but the CBO-virus consistently failed to cause detectable symptoms or lesions when inoculated by various routes into rabbits, guinea pigs, adult and suckling mice, ferrets, sheep and bovines, as well as young chicks and adult domestic fowls.

\section{Electrophoretic mobility of $\mathrm{CBO}$ virus particles}

Three different electrophoresis experiments were done (Fig. 1). The two peaks indicate that the infective particles are electrophoretically inhomogeneous. These diagrams are quite different from those obtained by the same technique from the three groups of viruses isolated by Alexander et al. (1957) from bovines with lumpy skin disease (Polson, unpublished). No further characters have been ascribed to these two electrophoretically distinct components of the $\mathrm{CBO}$ virus.

\section{Ultracentrifugation}

Five experiments were done to determine the relationship between virus titre and the speed of centrifugation. The results (Fig. 2) show the presence in infected tissue culture fluid of virus particles having sedimentation constants of $460 \mathrm{~S}$ and $72 \mathrm{~S}$. Experiments with fluid from which the $460 \mathrm{~S}$ particles had been removed by centrifugation at $10,000 \mathrm{rev} . / \mathrm{min}$. for $90 \mathrm{~min}$. revealed, in addition to the $72 \mathrm{~S}$ particles, a small proportion of very light infective units which were not completely sedi- 
mented during prolonged centrifugation at $30,000 \mathrm{rev} . / \mathrm{min}$. and had a sedimentation constant less than $20 \mathrm{~S}$.

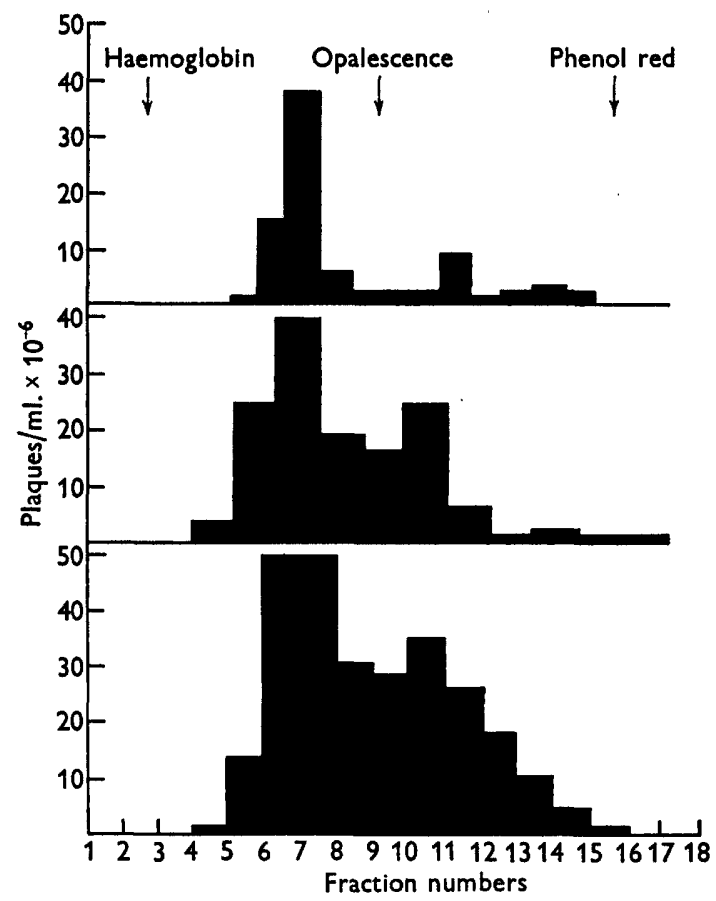

Fig. 1. Zone electrophoretograms of CBO virus in a sucrose density gradient at $\mathrm{pH} 8 \cdot 6$, $3.5 \mathrm{~V} . / \mathrm{cm}$. and $15 \mathrm{~mA}$.; phenol red and rabbit haemoglobin were added to indicate the progress of electrophoresis. The two peaks indicate inhomogeneity of the virus.

\section{Chromatography on DEAE cellulose}

Most of the virus was eluted at $\mathrm{NaCl}$ molarities between 0.2-0.3 (Fig. 3). About $10 \%$ of the virus appeared to be eluted at a slightly lower salt concentration than the component in the main peak.

\section{Adsorption of $\mathrm{CBO}$ virus to red cells}

Attempts were made to agglutinate various washed red cells with virus obtained from chick embryo tissue culture. These experiments were conducted at $4^{\circ}$, at room temperature and at $37^{\circ}$ in a range of $\mathrm{pH}$ values from $6 \cdot 0$ to 7.6. All were negative. Virus suspensions concentrated by centrifugation to a titre of $4 \times 10^{8}$ p.f.u. $/ 0 \cdot 2 \mathrm{ml}$. failed to agglutinate fowl and goose red cells even when followed by CBO fowl antiserum. However, adsorption of the virus by goose and fowl red cells was indicated by centrifuging mixtures of cells and virus after $3 \mathrm{hr}$. contact at $4^{\circ}$ and titrating the supernatant fluid and the lysed sediment brought to the original volume (Table 3). The virus was eluted when the cells were lysed in distilled water. Since many normal sera were known to contain inhibitors capable of neutralizing the $\mathrm{CBO}$ virus, the effects of enzymes on the sites of adsorption of the virus particles on the red cells were tested. RDE effectively decreased the number of receptor sites on fowl cells for the CBO virus (Table 4). The virus itself, however, lacked enzyme activity of the 


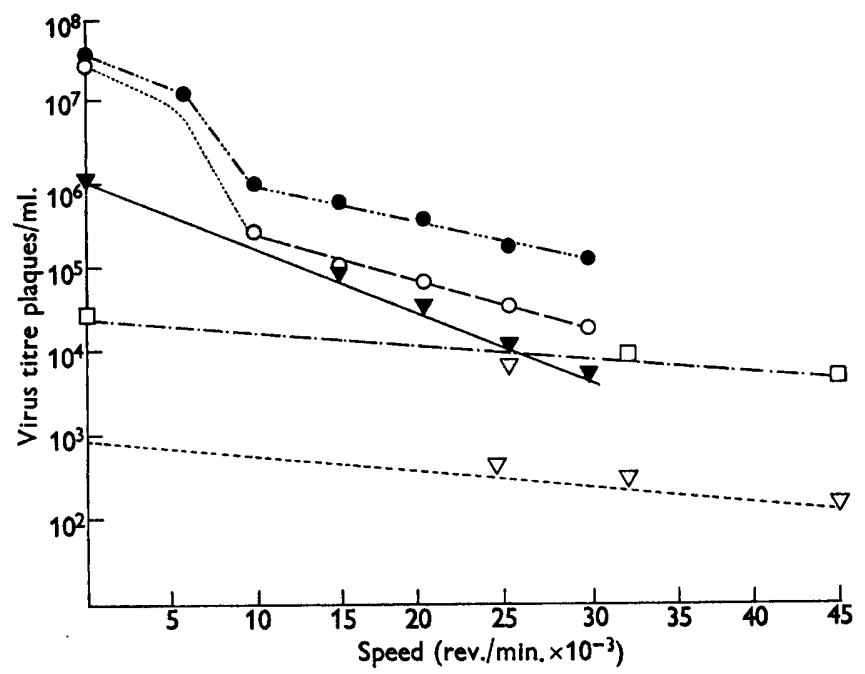

Fig. 2. Sedimentation diagrams of CBO virus. The infective titre of the fluid in the $1 \mathrm{~cm}$. column above a level $7 \cdot 1 \mathrm{~cm}$. from the centre of rotation is plotted against the speed of centrifugation. The duration of centrifugation was $90 \mathrm{~min}$. in all cases.

Titre of original virus suspension spun at the speeds indicated and showing the presence of rapidly and slowly sedimenting components; $\mathrm{O}-\mathrm{C}$, repeat of first experiment (dotted line imaginary); $\nabla-\nabla$, titre of virus suspension after centrifugation of the material from which the rapidly sedimenting components had been removed by 10,000 rev./min. for $90 \mathrm{~min}$; $\square-.-\cdot \square$, titre of virus suspension after centrifugation of the material from which the fast and the slower sedimenting components had been removed by $30,000 \mathrm{rev} . / \mathrm{min}$. for $90 \mathrm{~min} . ; \nabla \cdots \cdots-\nabla$, titre of virus suspension after centrifugation at $25,000 \mathrm{rev} . / \mathrm{min}$. for $90 \mathrm{~min}$. to remove the particle of $20 \mathrm{~S}=72$ and spun again at the velocities indicated.

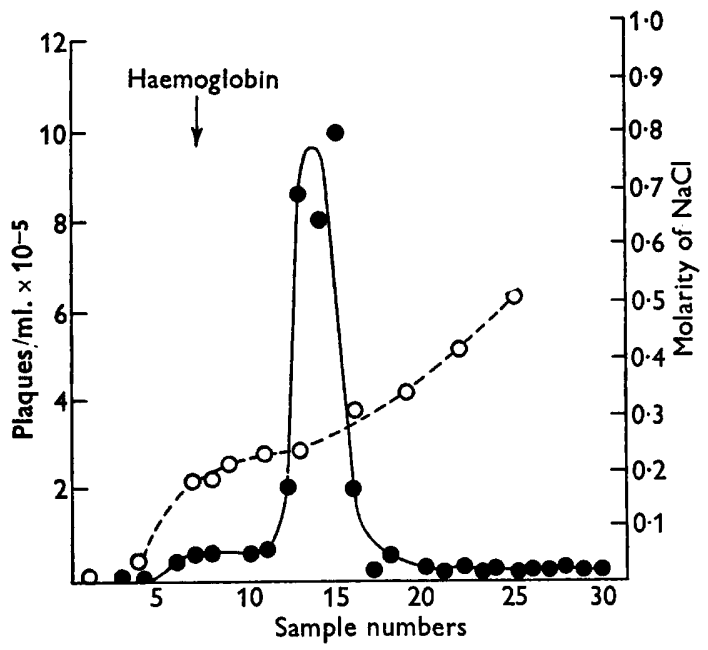

Fig. 3. Chromatography of CBO virus on DEAE cellulose. The bulk of the virus is eluted at concentrations between $0 \cdot 2-0 \cdot 3 \mathrm{M}-\mathrm{NaCl}$, but about $10 \%$ of the virus elutes at slightly lower salt concentrations. The arrow marks position at which rabbit haemaglobin elutes. Virus titre; $\mathrm{O}$, molarity of $\mathrm{NaCl}$. 
type exhibited by influenza virus, since adsorbed CBO virus did not elute at $37^{\circ}$ and treatment of fowl cells with $\mathrm{CBO}$ virus did not reduce their agglutinability by influenza $B$ virus (Lee).

Table 3. The adsorption of CBO virus to goose and forvl cells

Adsorption $3 \mathrm{hr}$. at $4^{\circ} ; 2 \mathrm{ml}$. packed cells and $0.5 \mathrm{ml}$. virus suspension.

$\begin{array}{cc}\text { Virus titre } \\ \text { Sample } & \text { (p.f.u./ml.) }\end{array}$

(1) Original untreated virus suspension

(2) Virus suspension after adsorption with goose RBC's

(3) Laked goose RBC's used for adsorption

(4) Virus suspension after adsorption with fowl RBC's

(5) Laked fowl RBC's used for adsorption
$2 \cdot 0 \times 10^{6}$

$8.0 \times 10^{4}$

$3.5 \times 10^{6}$

$1.7 \times 10^{5}$

$5 \cdot 0 \times 10^{6}$

Table 4. Adsorption of CBO virus to fowl red cells after treatment of cells with $R D E$

$2 \mathrm{ml}$. packed cells $+10 \mathrm{ml}$. RDE at $37^{\circ}$ for $2 \mathrm{hr}$. washed $\times 5$ in saline then $2 \mathrm{ml}$. packed cells $+0.5 \mathrm{ml}$. virus; $3 \mathrm{hr}$. at $4^{\circ}$.

\section{Sample}

(1) Original untreated virus suspension

(2) Virus suspension after adsorption with buffer treated cells

(3) Virus suspension after adsorption with RDE treated cells

\author{
Virus titre \\ (p.f.u./ml.) \\ $4.0 \times 10^{6}$ \\ $2.0 \times 10^{5}$ \\ $6 \cdot 0 \times 10^{8}$
}

\section{DISCUSSION}

The findings of Alexander et al. (1957) make it improbable that the CBO virus has any etiological relationship to bovine lumpy skin disease. This virus, isolated from a skin nodule of a calf in the acute stages of the disease, produced characteristic lesions in chick embryos which have been previously described (Van den Ende $e t$ al. $1948,1949)$. CBO virus was readily adapted to growth in cultures of chick embryo cells, and produced well defined plaques in agar suspension cultures of chick embryo cells (Cooper, 1955). Tissue culture fluid frequently contained more than $10^{6}$ p.f.u./ $\mathrm{ml}$. Physical studies of this virus facilitated by the plaque count technique showed that it was inhomogeneous. Plaques of two sizes were always seen. Infective particles of at least three sizes were detectable by centrifugation, but the finding that one infective particle has a sedimentation constant of $20 \mathrm{~S}$ or less is of some interest. The slow sedimentation of this component may be due to a high degree of asymmetry (a filamentous particle perhaps?) or to a diminished particle density owing to the presence of lipid. The particle of $72 \mathrm{~S}$ corresponding to $19 \mathrm{~m} \mu$ may be compared with the virus of foot and mouth disease which has a similar sedimentation constant (Bradish \& Brooksby, 1960). We have not been able to relate the differences in plaque morphology with differences in sedimentation constants. If all the virus particles carried the same surface charge density irrespective of size, all should migrate together in an electric field. Electrophoresis of the virus, however, revealed the presence of at least two electrophoretic components. Whether these correspond with the two larger components separated by ultracentrifugation and which account for nearly all the infectivity, has not been determined. The behaviour of the virus 
on electrophoresis was, however, quite different from that of any of the virus strains associated with bovine lumpy skin disease (Polson, unpublished). Inhibition of the infectivity of CBO virus by normal sera of several animal species has complicated serological studies, and investigation of this inhibitor is the subject of another paper (Turner et al. 1961). Although the virus is adsorbed by fowl and goose red cells, all attempts to demonstrate haemagglutination either directly or indirectly, were unsuccessful; nor was any evidence obtained of enzyme activity similar to that of the influenza viruses. The characters of the ECBO viruses are not yet sufficiently defined to be able to decide whether the CBO virus belongs to this group but some points of similarity make it a possibility.

\section{REFERENCES}

Alexander, R. A., Plowright, W. \& Haig, D. A. (1957). Cytopathogenic agents associated with lumpy skin disease of cattle. Bull. epiz. Dis. Afr. 5, 489.

Bradish, C. J. \& Brooksby, J. B. (1960). Complement-fixation studies of the specificity of the interactions between components of the virus system of foot-and-mouth disease and its antibodies. J. gen. Microbiol. $22,405$.

Cooper, P. D. (1955). A method for producing plaques in agar suspensions of animal cells. Virology, 1, 397.

Dulbecco, R. (1952). The production of plaques in monolayer tissue cultures by single particles of an animal virus. Proc. nat. Acad. Sci. Wash. 38, 8, 747.

Peterson, E. A. \& Sober, H. A. (1956). Chromatography of protein. I. Cellulose ion exchange adsorbents. J. Amer. chem. Soc. 78, 751.

Polson, A. \& Cramer, R. (1958). Zone electrophoresis of type I poliomyelitis virus. Biochim. biophys. Acta, 29, 187.

Polson, A. \& Turner, G. S. (1954). pH stability and purification of lumpy skin disease virus. J. gen. Microbiol. 11, 228.

Turner, G. S., Kipps, A., Polson, A. \& van den Ende, M. (1961). Neutralization of a cytopathogenic bovine orphan virus in tissue culture by heat stable Francis type inhibitors in normal animal sera. J. gen. Microbiol. 26, 415.

van den Ende, M., Alexander, R. A., Don, P. A. \& Kipps, A. (1948). Isolation in chick embryos of a filtrable agent possibly related etiologically to lumpy skin disease of cattle. Nature, Lond. 161, 526.

VAN DEN Ende, M., Don, P. A. \& KipPs, A. (1949). The isolation in eggs of a new filtrable agent which may be the cause of bovine lumpy skin disease. J. gen. Microbiol. 3, 174.

van Den Ende, M. \& Turner, G. S. (1950). Further observations on a filtrable agent isolated from bovine lumpy skin disease. J. gen. Microbiol. 4, 225. 